\title{
Rabies outbreak in buffaloes in Rio Grande do Sul, Brazil
}

\author{
Ronaldo Michel Bianchi ${ }^{1}$ Welden Panziera ${ }^{1}$ Glauco José Nogueira de Galiza ${ }^{2}$ \\ Glaucia Denise Kommers ${ }^{1}$ Rafael Almeida Fighera ${ }^{1^{*}}$
}

'Laboratório de Patologia Veterinária (LPV), Centro de Ciências Rurais (CCR), Universidade Federal de Santa Maria (UFSM), Av. Roraima, 1000, Bairro Camobi, 97105-900, Santa Maria, RS, Brasil. E-mail: anemiaveterinaria@yahoo.com.br. "Corresponding author. ${ }^{2}$ Laboratório de Patologia Animal, Centro de Saúde e Tecnologia Rural (CSTR), Universidade Federal de Campina Grande (UFCG), Patos, PB, Brasil.

\begin{abstract}
This report aimed to describe the clinical, epidemiological and pathological aspects of an outbreak of rabies in buffaloes in Rio Grande do Sul (RS), Brazil. Seven out of 41 buffaloes from the same farm became fatally ill; they showed the clinical signs of ataxia, ascending paresis, and paralysis of the limbs. During necropsy, marked hyperemia of the leptomeningeal vessels, and severe distention of the urinary bladder were noted. Histologically, there were indications of nonsuppurative meningoencephalitis and ganglioneuritis with intracytoplasmic and eosinophilic inclusion bodies in the neurons. The fluorescent antibody test was positive for rabies. Viral antigens were also detected by immunohistochemistry (IHC) in sections of the cerebellum. These results allowed for the definitive diagnosis of rabies, which is uncommonly reported in buffaloes.

Key words: buffaloes, rabies virus, Brazil, immunohistochemistry.
\end{abstract}

Surtos de raiva em bubalinos no Rio Grande do Sul, Brasil

RESUMO: Este relato objetiva descrever os aspectos epidemiológicos, clínicos e anatomopatológicos de um surto de raiva em bubalinos no Rio Grande do Sul (RS), Brasil. Adoeceram e morreram sete de um total de 41 búfalos de uma mesma propriedade, com sinais clínicos de incoordenação motora, paresia ou paralisia ascendentes dos membros. Durante a necropsia, observou-se marcada hiperemia dos vasos das leptomeninges e acentuada distensão da vesícula urinária por urina. Histologicamente havia meningoencefalite e ganglioneurite não supurativas associadas a corpúsculos de inclusão intracitoplasmáticos e eosinofilicos em neurônios. O teste de imunofluorescência direta foi positivo para raiva. O antígeno viral também foi detectado em seções do cerebelo por meio da imuno-histoquímica (IHQ). A associação destes resultados permitiu o diagnóstico definitivo de raiva, uma doença pouco relatada em bubalinos.

Palavras-chave: búfalos, vírus da raiva, Brasil, imuno-histoquímica.

Rabies is an infectious disease caused by an enveloped RNA virus of the Rhabdoviridae family and the Lyssavirus genus (RODRIGUEZ et al., 2012), which affects the central nervous system (CNS) of several mammalian species (ECCO et al., 2016). In the bovidae family, the disease is most commonly reported in cattle (SANCHES et al., 2000; LANGOHR et al., 2003; MARCOLONGOPEREIRA et al., 2011) and infrequently in buffaloes (JAMADAGNI et al., 2007; SINGH \& SANDHU, 2008; ZHANG et al., 2011; EL-THOLOTH et al., 2015). In these species, the main transmitters are hematophagous bats, particularly Desmodus rotundus, which inoculate the virus present in the saliva during blood feeding (BARROS et al., 2006).
This report aimed to describe an outbreak of rabies affecting buffaloes in the state of RS, Brazil. Epidemiological, clinical, and pathological aspects are described, highlighting the effectiveness of immunohistochemical tests as an additional tool in the diagnosis of rabies.

To confirm the diagnosis, a six-monthold, male buffalo was submitted for necropsy. Epidemiological and clinical data were obtained from the owner. During necropsy, the brain, trigeminal ganglia, and fragments of several tissues were collected. Samples of the cerebellum, parietal cerebrum, thalamus, and the cervical spinal cord (C1$\mathrm{C} 2$ ), were refrigerated and sent to the Virology Sector of the Universidade Federal de Santa Maria for a direct 
fluorescent antibody test (DFA). The remainder of the brain and tissue samples were fixed in $10 \%$ buffered formalin for 24 hours and processed routinely for histology and stained by hematoxylin-eosin (HE). Immunohistochemistry was performed in a section of the cerebellum. Antigen retrieval was performed with citrate solution ( $\mathrm{pH}$ 6.0) and heat in a microwave oven. A rabies polyclonal antibody (Chemicol \#5199) was used as the primary antibody in a dilution of 1:1000. The biotinylated secondary antibody and streptavidin-biotin-peroxidase complex (LSAB + System HRP, Dako) were used consecutively and labeled by the addition of Liquid DAB + Substrate Chromogen System (Dako).

The outbreak occurred in a farm in the county of Vale Verde, RS, Brazil, a region considered endemic to bovine rabies. The herd composed of 24 adults and 17 young buffaloes (between three and six-month-old). Seven out of 41 buffaloes became fatally ill (morbidity and mortality rate of $17.1 \%$ ), and those that became fatally ill were young (morbidity and mortality rate of $41 \%$ [7/17] in this age group). Deaths occurred between late July and early September, 2013. Buffaloes of the herd were annually vaccinated for rabies, with the most recent vaccination performed in May 2013. However, during the outbreak, the younger buffaloes had only received a single dose of the vaccine and had yet to receive the booster shot.

Buffaloes showed neurological signs characterized by motor incoordination and falls with a progression toward permanent decubitus, first sternal and then lateral. This was then accompanied by reports of paddling movements, opisthotonus, nystagmus, bruxism, salivation, and muscle tremors in the head among those that were fatally ill. The clinical course ranged between three to five days, followed by spontaneous death.

During necropsy, marked hyperemia of the meninges of the brain was noted (Figure 1A). The urinary bladder was also markedly distended with urine. The left pulmonary lobes were firm, wavy and dark red, with intraluminal vegetable fibers in large bronchi.

Histologically, in the different sections of the brain (cerebellum, medulla oblongata at the obex, pons, and the midbrain, thalamus, basal nuclei, hippocampus, and the frontal, parietal and the occipital cerebrum), severe inflammatory infiltrate surrounding the blood vessels was evident in the neuroparenchyma, which were composed of several layers of lymphocytes, plasma cells and macrophages (perivascular cuffing) (Figure 1B). Inflammatory infiltrate was also similarly noted in the meninges. The glial cells and astrocytes were diffusely hyperplastic (gliosis and astrocytosis). Within the trigeminal ganglia, severe mononuclear inflammatory infiltrate was evident, in addition to the incidence of neuronal necrosis and neuronophagia (Figure 1C). Multiple intracytoplasmic and eosinophilic inclusions (Negri bodies) were observed in the neurons of the brain (Figure 1D) and the trigeminal ganglia (Figure 1C). In the lung, lumens of the bronchioles and bronchi were obliterated due to the presence of marked neutrophilic inflammatory infiltrate, admixed to plant material (aspiration pneumonia), with the incidence of alveolar edema noted.

The IHC and DFA results were positive for rabies (Figures 1E e 1F). IHC detected large amounts of viral antigens evident as granular accumulations, or as larger, solitary to multiple, and round to oval aggregates in the Purkinje cells, the neurons of the granular layer, and in the axonal filaments of the molecular layer of the cerebellum.

Clinical and pathological findings associated with the detection of viral antigens based on the IHC and DFA tests allowed for the definitive diagnosis of rabies in these buffaloes. In general, the incidence of rabies is not predisposed toward a particular breed, sex, or age group. However, there are indications that the disease is more frequent among cattle that are less than one-year-old. Therefore, this observation is most likely related to the immune status of the animal because at this age, there is a decline in passive immunity, and the initial course of the rabies vaccine or booster shot has yet to be administered (FERNANDES \& RIET-CORREA, 2007). During this particular outbreak, the young buffaloes that were affected were aged between three and six months old, and had only received one dose of the rabies vaccine.

The affected buffaloes in this outbreak showed clinical signs consistent with the paralytic form of the disease, similar to the few cases of bubaline rabies reported in the literature (SINGH \& SANDHU, 2008; MUGALE et al., 2013). The average clinical course was four days; in herbivores, the clinical course can range between two and ten days (LANGHOR et al., 2003). Gross and histologic findings were also similar to those reported in the cases of bubaline (JAMADAGNI et al., 2007; MUGALE et al., 2013; EL-THOLOTH et al., 2015) and bovine rabies (BARROS et al., 2006; FERNANDES \& RIET-CORREA, 2007). The incidence of aspiration pneumonia and the distention of the urinary bladder are secondary changes to the neurological impairment caused by the virus affecting the CNS 


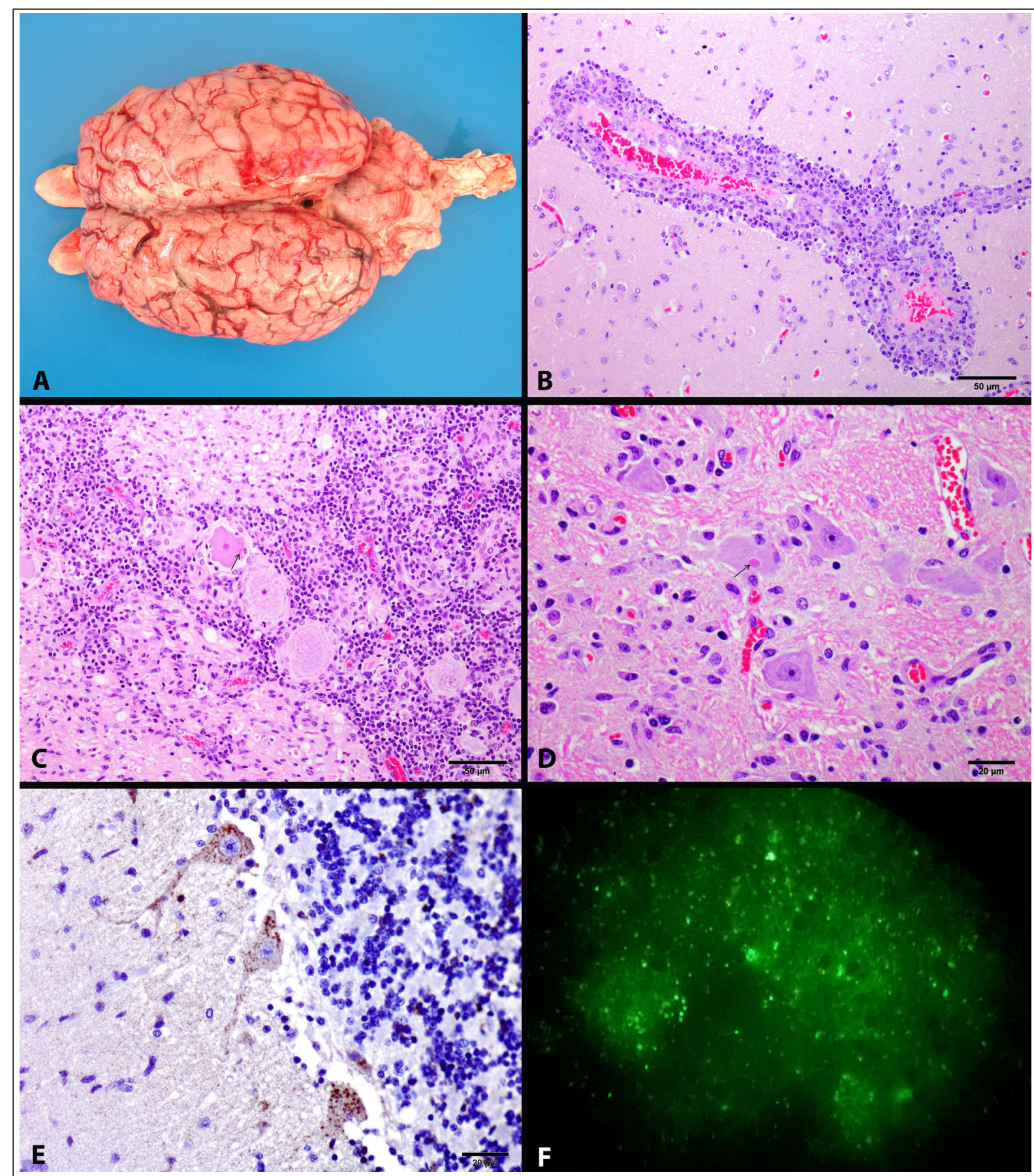

Figure 1 - Rabies in buffaloes. (A) Leptomeningeal blood vessels of the brain are markedly hyperemic. (B) Perivascular cuffing consists of lymphoplasmacytic inflammatory infiltrate. Note the distention of the perivascular space by multiple layers of inflammatory cells. H\&E, magnification 20×. (C) Marked mononuclear inflammatory infiltrate is noted to be distributed diffusely between the neurons of the trigeminal ganglia. In the center, note the necrotic neuron surrounded by glial cells (neuronophagia) with an intracytoplasmic Negri body (arrow). H\&E, magnification 20×. (D) Neuron with Negri body (arrow). H\&E, magnification 40×. (E) Marked immunolabeling showed evidence of the presentation of viral antigens in multiple granules in the cytoplasm of Purkinje cells of the cerebellum. IHC, magnification 40×. (F) Direct fluorescent antibody was marked positive for rabies.

and occur, respectively, by neurological dysphagia and viral myelitis (BARROS et al., 2006). The incidence of nonsuppurative meningoencephalitis and ganglionitis with Negri bodies in the neurons are typical histologic findings and fundamental to the diagnosis (BARROS et al., 2006).

Ciência Rural, v.47, n.4, 2017. 
DFA is the choice test for the official diagnosis of rabies due to its speed and accuracy (RODRIGUEZ et al., 2012). Conversely, IHC allows for the detection of viral antigens in formalin fixed tissues and is extremely specific for confirming the diagnosis. In addition, IHC has been used as an additional tool in the diagnosis of rabies in humans and animals, especially in cases involving nonsuppurative meningoencephalitis without Negri bodies, and when DFA is negative (PEDROSO et al., 2008; RISSI et al., 2008). Furthermore, the detection of the rabies viral antigen in nervous tissue showing autolysis has been reported (ARSLAN et al., 2004). In this outbreak, both tests were markedly positive.

The main differential diagnoses included meningoencephalitis caused by bovine herpesvirus 5 (SCHEFFER, 2013), malignant catarrhal fever (MARTUCCIELLO et al., 2006), polioencephalomalacia (SANT'ANA et al., 2009), poisoning plants that cause hepatic encephalopathy (CORRÊA et al., 2008), listeriosis (RIET-CORREA et al., 1998), botulism (SILVA et al., 1998), and tetanus (BARBOSA et al. 2009).

Our results indicated that rabies in buffaloes is similar to bovine rabies. Although rabies has been an underreported disease in buffaloes, the disease should gain more attention due to the constant growth of the Brazilian buffalo herd, and due to the fact that it is a fatal zoonosis. Therefore, it is important that the disease should be included as part of the differential diagnosis for diseases that cause neurological signs.

\section{BIOETHICS AND BIOSSECURITY COMMITTEE APPROVAL}

We authors of the article entitled "Rabies outbreak in buffaloes at Rio Grande do Sul, Brazil" declared, for all due purposes, that the project that gave rise to the present data has not been submitted for evaluation to the Ethics Committee of the Universidade Federal de Santa Maria (UFSM), but we are aware of the content of the Brazilian resolutions of the National Council for Control of Animal Experimentation - CONCEA <http://www.mct. gov.br/index.php/content/view/310553.html > if it involves animals.

Thus, the authors assume full responsibility for the presented data and are available for possible questions, if they should be required by the competent authorities.

\section{REFERENCES}

ARSLAN, A. et al. Detection of rabies viral antigens in nonautolysed and autolysed tissues by using an immuno-peroxidase technique. Veterinary Record, v.155, p.550-552, 2004. Available from: <http://veterinaryrecord.bmj.com/content/155/18/550.long $>$. Accessed: July 10, 2015. doi: 10.1136/vr.155.18.550.

BARBOSA, J. D. et al. Outbreak of tetanus in bufalloes (Buballus bubalis) in Pará, Brazil. Pesquisa Veterinária Brasileira, v.29, p.263-265, 2009. Available from: <http://www.scielo.br/pdf/pvb/ v29n3/13.pdf $>$. Accessed: July 10, 2015. doi: 10.1590/S0100736X2009000300013.

BARROS, C. S. L. et al. Raiva. In:___. Doenças do sistema nervoso de bovinos no Brasil. Monte Carlos (MG): Vallé, 2006. Cap.5, p.21-28.

CORRÊA, A. M. R. et al. Senecio brasiliensis (Asteraceae) poisoning in Murrah buffaloes in Rio Grande do Sul. Pesquisa Veterinária Brasileira, v.28, p.187-189, 2008. Available from: <http://www. scielo.br/pdf/pvb/v28n3/10.pdf>. Accessed: July 10, 2015.

ECCO, R. et al. Sistema nervoso. In: SANTOS, R. L.; ALESSI, A. C. Patologia veterinária. 2. ed. Rio de Janeiro: Roca, 2016. Cap.8, p.487-572.

EL-THOLOTH, M. et al. Identification and genetic characterization of rabies virus from Egyptian water buffaloes (Bubalus bubalis) bitten by a fox. Virus Disease, v.26, p.141-146, 2015. Available from: $<$ http://link.springer.com/article/10.1007\%2Fs13337-015-0263-y\#/ page-1>. Accessed: July 05, 2016. doi: 10.1007/s13337-015-0263-y.

FERNANDES, C. G.; RIET-CORREA, F. Raiva. In: RIETCORREA, F. et al. Doenças de ruminantes e equídeos. 3. ed. Santa Maria: Pallotti, 2007. p.184-198.

JAMADAGNI, S. B. et al. Histopathological alterations in brains of rabies infected buffaloes and cattle. Italian Journal of Animal Science, v.6, p.872-874, 2007. Available from: <http://www. tandfonline.com/doi/pdf/10.4081/ijas.2007.s2.872>. Accessed: June 20, 2015. doi: 10.4081/ijas.2007.s2.872.

LANGOHR, I. M. et al. Epidemiology, clinical signs and distribution of lesions in the brain of rabid cattle. Ciência Rural, v.33, p.125-131, 2003. Available from: <http://www.scielo.br/ pdf/cr/v33n1/14154.pdf>. Accessed: June 20, 2015. doi: 10.1590/ S0103-84782003000100020.

MARCOLONGO- PEREIRA, C. et al. Rabies in cattle in southern Rio Grande do Sul: Epidemiology and immunohistochemistry diagnosis. Pesquisa Veterinária Brasileira, v.31, p.331-335, 2011. Accessed: June 20, 2015. doi: 10.1590/S0100-736X2011000400010.

MARTUCCIELLO, A. et al. An outbreak of malignant catarrhal fever in Mediterranean water buffalo (Bubalus bubalis). Large Animal Review, v.12, p.21-24, 2006. Available from: <http://www.vetjournal. it/archivio/archivio_pdf/2006/3965.pdf $>$. Accessed: July 10, 2015.

MUGALE, M. et al. Histopathological alterations in nervous system of rabid animals. Indian Journal of Animal Science, v.83, p.736-738, 2013. Available from: <https://www.researchgate. net/profile/Naresh_kumar_Sood2/publication/25647471.pdf >. Accessed: June 20, 2015.

PEDROSO, P. M. O. et al. Standardization of immunohistochemistry technique for detection of rabies virus in formalin-fixed and paraffinembedded tissue samples from central nervous system of cattle. Pesquisa Veterinária Brasileira, v.28, p.627-632, 2008. Available from: <http:// www.scielo.br/pdf/pvb/v28n12/a12v2812.pdf >. Accessed: June 20, 2015. doi: 10.1590/S0100-736X2008001200012.

RIET-CORREA, F. et al. Neurological diseases in ruminants in southern brazil. Ciência Rural, v.28, p.341-348, 1998. Available from: <http://www.scielo.br/pdf/cr/v28n2/a28v28n2.pdf>. Accessed: July 10, 2015. doi: 10.1590/S0103-84781998000200028. 
RISSI, D. R. et al. Occurrence of rabies in sheep in Rio Grande do Sul, Brazil. Pesquisa Veterinária Brasileira, v.28, p.495-500, 2008. Available from: <http://www.scielo.br/pdf/pvb/v28n10/ v28n10a09.pdf>. Accessed: June 20, 2015. doi: 10.1590/S0100$736 \times 2008001000009$.

RODRIGUEZ, L. L. et al. Rhabdoviridae. In: FLORES, E. F. Virologia veterinária. 2. ed. Santa Maria: UFSM, 2012. Cap.28, p.795-830.

SANCHES, A. W. D. et al. Diseases of the central nervous system in cattle of southern Brazil. Pesquisa Veterinária Brasileira, v.20, p.113-118, 2000. Available from: <http://www.scielo.br/pdf/pvb/ v20n3/2729.pdf>. Accessed: June 20, 2015. doi: 10.1590/S0100$736 \times 2000000300005$.

SANT'ANA, F. J. F. et al. Polioencephalomalacia in ruminants. Pesquisa Veterinária Brasileira, v.29, p.681-694, 2009. Available from: <http://www.scielo.br/pdf/pvb/v29n9/ a01v29n9.pdf $>$. Accessed: July 10, 2015. doi: 10.1590/S0100736X2009000900001
SCHEFFER, C. M. Herpesvírus e pestivírus em rebanhos bubalinos do Rio Grande do Sul. 2013. 98f. Dissertação (Mestrado em Microbiologia Veterinária - Virologia) - Programa de Pós-graduação em Ciências Veterinárias, Universidade Federal do Rio Grande do Sul, RS.

SILVA, T. M. D. et al. Occurrence and distribution of Clostridium botulinum type $\mathrm{C}$ and $\mathrm{D}$ spores in buffalo breeding areas of the Baixada Maranhense, Maranhão, Brazil. Pesquisa Veterinária Brasileira v.18, p.127-131, 1998. Available from: <http://www.scielo.br/scielo. phpS0100-736X1998000300007>. Accessed: July 10, 2015. doi: 10.1590/S0100-736X1998000300007.

SINGH, C. K.; SANDHU, B. S. Rabies in SouthAsia: epidemiologica investigations and clinical perspective. Developments in biological, v.131, p.133-136, 2008. Available from: <http://www.ncbi.nlm.nih gov/pubmed/18634472>. Accessed: July 05, 2016.

ZHANG, K. et al. Diagnosis and molecular characterization of rabies virus from a buffalo in China: a case report. Virology Journal, v.8, p.101, 2011. Available from: <http://virologyj.biomedcentral.com/ articles/10.1186/1743-422X-8-101>. Accessed: July 05, 2016. 